\title{
Discovery of anticancer agents of diverse natural origin ${ }^{*}$
}

\author{
A. Douglas Kinghorn ${ }^{1, \dagger}$, Esperanza J. Carcache de Blanco ${ }^{1}$, Hee-Byung Chai ${ }^{1}$, Jimmy \\ Orjala $^{2}$, Norman R. Farnsworth ${ }^{2}$, D. Doel Soejarto ${ }^{2}$, Nicholas H. Oberlies ${ }^{3}$, Mansukh C. \\ Wani $^{3}$, David J. Kroll ${ }^{3} \ddagger$, Cedric J. Pearce ${ }^{4}$, Steven M. Swanson ${ }^{2}$, Robert A. Kramer ${ }^{5}$, William \\ C. Rose ${ }^{5}$, Craig R. Fairchild ${ }^{5}$, Gregory D. Vite ${ }^{5}$, Stuart Emanuel ${ }^{5}$, David Jarjoura ${ }^{6}$, and \\ Frederick O. Cope ${ }^{6}$ \\ ${ }^{1}$ College of Pharmacy, The Ohio State University, Columbus, OH 43210, USA \\ ${ }^{2}$ College of Pharmacy, The University of Illinois at Chicago, Chicago, IL 60612, USA \\ ${ }^{3}$ Research Triangle Institute, Research Triangle Park, NC 27709, USA \\ ${ }^{4}$ Mycosynthetix, Inc., Hillsborough, NC 27278, USA \\ ${ }^{5}$ Bristol-Myers Squibb, Pharmaceutical Research Institute, Princeton, NJ 08543, USA \\ ${ }^{6}$ Comprehensive Cancer Center, The Ohio State University, Columbus, OH 43210, USA
}

\begin{abstract}
A collaborative multidisciplinary research project is described in which new natural product anticancer drug leads are obtained from a diverse group of organisms, constituted by tropical plants, aquatic cyanobacteria, and filamentous fungi. Information is provided on how these organisms are collected and processed. The types of bioassays are indicated in which crude extracts of these acquisitions are tested. Progress made in the isolation of lead bioactive secondary metabolites from three tropical plants is discussed.
\end{abstract}

\section{Keywords}

natural products; plants; cyanobacteria; fungi; anticancer activity

\section{INTRODUCTION}

Cancer is responsible for about one in every four deaths in the United States and is therefore a major public health burden. The American Cancer Society projects that in 2008, there will be over 1.4 million new cases of invasive cancer diagnosed and over 565,000 deaths from cancer, or more than 1,500 deaths each day. The major cancer mortalities in the U.S. result from cancers of the lung and bronchus, prostate, and colon and rectum in men, and of the lung and bronchus, breast, and colon and rectum in women [1]. Developing countries are being increasingly afflicted with cancer, as their populations live longer and make negative lifestyle changes associated with increased cancer risk [2.3]. Accordingly, the threat of cancer will be of major concern for the foreseeable future for those in both developed and developing countries. Cancer chemotherapy is an important alternative to surgery and radiation to treat

\footnotetext{
*Plenary lecture presented at the International Conference on Biodiversity and Natural Products (ICOB-6 \& ISCNP-26), Charlottetown, Prince Edward Island, Canada, 13-18 July 2008.

†Corresponding author. kinghorn.4@osu.edu.

¥Present address: Department of Pharmaceutical Sciences, Biomanufacturing Research Institute and Technology Enterprise (BRITE), North Carolina Central University, Durham, NC 27707, USA.
} 
successfully some types of solid tumors, lymphomas, and leukemias, and many clinically approved cytotoxic and antiproliferative anticancer drugs are available, both of synthetic and natural product (microbial and plant) origin $[4,5]$. However, much progress needs to be made to overcome the problems of resistance to and toxicity of existing cancer chemotherapeutic agents $[4,5]$. It is expected that in the future, anticancer drug discovery will need to focus on mechanism-based agents that act on specific molecular targets associated with the etiology of cancer [6].

Natural product compounds have substantial structural diversity and frequently afford new mechanisms of biological activity. As a result, natural products are used widely in cancer chemotherapy [7]. Accordingly, there is a continued interest in the investigation of extracts of microorganisms, terrestrial plants, and marine life forms to search for further compounds of this type [7-10]. In a recent analysis of the antineoplastic agents marketed in western countries and Japan, it was revealed that of 155 compounds in total ever introduced since the 1940s, $47.1 \%$ were either unmodified natural products ( 25 compounds, $16.1 \%$ ) or semi-synthetic derivatives of natural products (48 compounds, 31.0\%) [9]. Natural product anticancer agents have been discovered and developed primarily by the pharmaceutical industry, but important contributions have been made by academic, governmental, and private research laboratories. In a recent major volume on promising compounds from nature as anticancer agents, there were six major classes from plants, seven from marine organisms, and ten from microbes, indicating that all types of organisms should be accessed to maximize the likelihood of discovering effective new cancer drugs [7]. Natural products are recognized as occupying a different region of "chemical space" than typical synthetic compounds [e.g., 11-13] and are an excellent source of novel chiral structures for synthetic and combinatorial chemistry modification for drug development [14].

In this short review, we will describe a new multi-institutional collaborative project funded by the U.S. National Cancer Institute (NCI), National Institutes of Health (NIH), Bethesda, Maryland, through the "program project" (P01) mechanism. This is a successor to a previous "National Cooperative Drug Discovery Groups" (NCDDG) project (U01/U19 mechanism), also funded by NCI, NIH, and involves the same four partners, namely, two academic groups (The Ohio State University and the University of Illinois at Chicago), a private, non-profit research institute (Research Triangle Institute, North Carolina), and an industrial partner (Bristol-Myers Squibb, Pharmaceutical Research Institute, Princeton, New Jersey). In this new project, however, there is now the participation of a biotechnology company, Mycosynthetix, Inc. (Hillsborough, North Carolina). Descriptions of our collaborative work on the former NCDDG project have been published previously $[15,16]$. In our new program project, in addition to investigating tropical plants, we are also targeting aquatic cyanobacteria and filamentous fungi for the discovery of potential new anticancer agents. In the following paragraphs we will briefly review progress made by others previously in terms of anticancer drug discovery among these three types of organisms.

For over a decade, members of four major groups of plant-derived anticancer agents have been available in the United States and elsewhere, including the vinca (Catharanthus) bisindole alkaloids, the epipodophyllotoxin analogs, the taxanes, and the camptothecins [4,5,7].

Moreover, the anticancer clinical development of over ten further derivatives of paclitaxel and camptothecin is currently taking place $[7,10,17]$. Several other plant-derived substances show potential for future use in cancer chemotherapy. A number of these compounds are already in clinical trials in the United States and/or in other countries. The compound perhaps closest to market approval is combretastatin A4 phosphate, a plant-derived stilbenoid with antimitotic and antiangiogenic activities [7,10]. Butler has recently reviewed the current oncology clinical trial status of several additional substances of plant origin, inclusive of the alkaloid, 
homoharringtonine; the benzopyran, phenoxodiol (a synthetic derivative of the isoflavone, diadzein); the diterpene ester, ingenol 3-O-angelate; and the isoflavone, genistein [10].

Cyanobacteria (blue-green algae) have been identified as a promising source of novel bioactive metabolites [18-22]. Prominent experimental anticancer agents include the cryptophycins from terrestrial blue-green algae $[7,23]$, and the dolastatins, originally derived from a seahare, Dolabella auricularia, but now found in certain marine cyanobacteria, and therefore thought to be of dietary origin [10,24]. Of these, dolastatins 10 and 15 are currently in oncology clinical trials [10]. A screening program on cultured cyanobacteria demonstrated that antineoplastic compounds are distributed widely among cyanophytes [25]. The rate of rediscovery of known bioactive compounds, however, is known to be significantly lower among the cyanobacteria than other microbial sources with similar hit rates such as actinomycetes. Despite this, cyanobacteria are relatively unexplored as potential anticancer agents, particularly from aquatic sources.

A number of fungal compounds have been investigated for anticancer activity [7,26], including brefeldin A [27], cytochalasin E [28], gliotoxin [29], illudin S [30], irofulven [10,31], the leptomycins [7], palmarumycin $\mathrm{CP}_{1}$ [7], terrecyclic acid A [32], and wortmannin [33], Most of these structurally diverse compounds were discovered thirty years or more ago, and at some later time shown to have potential anticancer activity. Irofulven, a DNA synthesis inhibitor based on the lead compound, illudin S, is now in late phase oncology clinical trials [10]. Recently, lodamin, a new angiogenesis inhibitor based on TNP-470, itself related to cytochalasin $\mathrm{E}$ and originally isolated from Aspergillus fumigatus fresenius and discovered through serendipidty in Folkman's laboratory [34] and then modified using nanotechnology, has shown promise in murine models of a number of cancer types [35].

\section{COLLECTION AND PROCESSING OF ORGANISMS}

A continued search for anticancer agents from tropical plants, aquatic cyanobacteria, and filamentous fungi should pay dividends, both in terms of the potential discovery of further examples of antitumor agents of natural origin and the favorable prospects of generating specific molecular probes germane to the biology of cancer. The strategies being used to collect and process these three basis types of organisms in our program project will be discussed briefly in turn.

In our former NCDDG project, the entire focus was on the discovery of plant-derived anticancer agents from understudied endemic species of tropical rainforest plants $[15,16]$. This is still a valid approach, since humid tropical forests sustain considerable biodiversity, and in some areas more tree species may be found in a $0.5 \mathrm{~km}^{2}$ area than in all of North America [36]. Moreover, some 25 biodiversity "hot spots" occur (44\% of all vascular species in $1.4 \%$ of the earth's land surface) [37], and it has been estimated that of the total number of higher plant species on earth $(310,000-422,000)$, about 120,000 are found in biodiversity "hot spots" that are under threat from massive habitat loss [38]. It has been calculated that as many as 60,000 species of flowering plants will have become extinct before the year 2050 [38]. Furthermore, so far as the tropical rain forests are concerned, they occupy only 7-8\% of the land surface of the earth, but offer a disproportionate opportunity for the discovery of structurally novel, pharmacologically active substances [39]. This has been attributed to elevated temperatures, high humidity and high species density, and a continuous growing season, resulting in the accumulation of specialized secondary metabolites by rainforest species as defensive mechanisms against predators and parasites, and as pollination attractants [40]. By concentrating on tropical rainforest plants rather than temperate species, it is hypothesized that greater chemical diversity will result. 
The approaches taken in plant collection have been discussed previously, inclusive of the development of benefit-sharing agreements, the use of the NAPRALERT database to select under-investigated endemic plants for subsequent laboratory study, and the types and numbers of plant parts collected per species $[15,16]$. A retrospective study has been conducted in which plant profiles (i.e., country of collection, taxonomy, and plant part) for acquisitions obtained for our former NCDDG project were compared with the resultant cytotoxic activity of extracts prepared from these samples, when evaluated against a panel of human tumor cell lines [41]. Altogether, over 2600 plant acquisitions were made over an approximately 15 -year period. On average, the most potently cytotoxic extracts were prepared from plants collected in Ecuador, out of six major tropical and sub-tropical countries and regions where plant collections were made. Of over 150 plant families collected, the most promising cytotoxic activities were from plants in the Clusiaceae, Elaeocarpaceae, Meliaceae, and Rutaceae. Particularly active genera from the over 650 represented were Aglaia, Casearia, Exostema, Mallotus, and Trichosanthus. In general, it was found that roots and other below-ground organs afforded more potently cytotoxic extracts than extracts prepared from above-ground plant parts [41]. For the ongoing program project work, it is proposed to supplement our existing plant holdings with new primary collections from Indonesia, Vietnam, and other countries. We are continuing to utilize a simple plant solvent extraction scheme, which has proved to be reproducible as used over the last decade [15,16,42]. Typically, only the organic-soluble extract (a chloroform extract treated with sodium chloride) for each plant acquisition is submitted for initial biological screening, with the remaining fractions (hexane wash and aqueous residue) retained in case of need. A dereplication method is applied to plant extracts to avoid the reisolation of previously known cytotoxic compounds [43].

In this collaborative work, aquatic cyanobacteria are being collected in part in the field, with some samples obtained from commercial sources. The latter group is represented by the Culture Collection of Algae at the University of Texas at Austin (UTEX), the Provasoli-Guillard National Center for the Culture of Marine Phytoplankton (CCMP), and the Culture Collection of Algae at the University of Gottingen (SAG). All taxonomic orders of cyanobacteria (viz., Chaetophorales, Chroococcales, Nostocales, Oscillatoriales, Pleurocapsales, and

Stigonematales) are present in our culture collection, which currently consists of over 300

cyanobacterial strains. Obstacles in studying the bioactive secondary metabolites of cyanobacteria are the slow growth rate and low biomass yield of these organisms in culture. To overcome these limitations, we use the recently developed micro-analytical technique of segmented flow analysis (SFA) microcoil NMR [44] to reduce the amounts of pure material needed for structure elucidation to only $\sim 50 \mu \mathrm{g}$. This typical initial small amount of compound isolated enables us not only to determine its structure but also to measure the level of activity against selected molecular targets. It also significantly lowers the amount of starting biomass required and we are able to perform most of our studies with a total fermentation volume of 4 L. Each strain is grown in two aerated $2.8 \mathrm{~L}$ Fernbach flasks with $2 \mathrm{~L}$ media for a total fermentation volume of $4 \mathrm{~L}$. The cells are harvested after $4-8$ weeks and separated by centrifugation. The freeze-dried biomass is subjected to extraction with methanol-

dichloromethane (1:1), with this organic extract then used for initial biological screening. Scale up and re-isolation of larger amounts of a natural product of interest for further biological and chemical evaluation is performed according to our program needs.

The program project has access to a library of over 55,000 filamentous fungi, housed at Mycosynthetix, Inc. Although acquisitions in this collection have been examined for drug leads for several different pharmaceutical and agrochemical applications in the past, this library has never been examined systematically as anticancer leads. It has been estimated that 1.5 million species of fungi exist in the world [45], and of these, only 70,000 have been subjected to taxonomic studies. Hence, the vast majority of fungi have never been tested for any kind of biological activity, let alone subjected to chemical evaluation. The Mycosynthetix fungal 
collection was established over the past two decades and was collected in the form of mycelia, rather than simply as spores. These samples were isolated and preserved from targeted ecosystems from around the world, after obtaining the necessary permissions.

Mycosynthetix has developed approaches to culturing fungi that supports the production of unusual metabolites, including the use of both liquid and solid media. In many instances, it has been observed that a particular metabolite is produced specifically under only one set of conditions. Diverse growth conditions are utilized to optimize the chances of discovering promising biological activity. This ability to culture and optimize the growth conditions of an organism presents a means to re-supply a large quantity of a promising lead compound. Prior to initial biological screening, fungal specimens are subjected to a two-stage culturing procedure, in both liquid seed and grain-based solid media. For initial biological testing, cultures are extracted with 1:1 chloroform-methanol, with organic and aqueous partitions being produced, and the organic extract partitioned into 1:1 acetonitrile-hexane.

\section{BIOLOGICAL EVALUATION OF SAMPLES}

Once initial crude extracts are prepared from tropical plants, aquatic cyanobacteria, and filamentous fungi, they are subjected to evaluation in a battery of cell-based and mechanismbased assays housed at the various locations where the laboratory work in our program project is carried out. Cytotoxicity assays using selected cancer cell lines are conducted at The Ohio State University [46], Research Triangle Institute [47], and Bristol-Myers Squibb [16], with in each case a focus on selectivity of activity. Some of the target-based assays that have been selected are the activation of nuclear factor- $\mathrm{\kappa B}(\mathrm{NF}-\mathrm{\kappa B})$ [48] and of nuclear factor of activated T cells (NFAT) [49,50], as well as a mitochondrial transmembrane potential (MTP) assay [51], at The Ohio State University; modulation of EZH2 levels and activity at Research Triangle Institute [52,53], and inhibition of histone deacetylase [54,55] and the 20S proteasome [56, 57] at the University of Illinois at Chicago. A key element of our group interaction is the prioritization of in vitro-active crude extracts for subsequent activity-guided purification [15, 16].

In an earlier review on our collaborative work on anticancer agents from natural sources, a detailed account was given as to how the in vivo hollow fiber assay is used [16]. This method was developed at the U.S. National Cancer Institute (NCI) [58-60] and transferred to the University of Illinois at Chicago nearly ten years ago [61]. In our hands, we have found this method to be a useful secondary assay to help determine if a given in vitro-active compound is likely to be active in a traditional xenograft assay [61]. In the hollow fiber assay, human cancer cells are propagated within fibers that are implanted either intraperitoneally (ip) or subcutaneously (sc), and this is quite rapid and inexpensive, and may require only $25 \mathrm{mg}$ of test compound for the total testing. For follow up in vivo investigations, we have used the P388 murine lymphocytic leukemia model [62] and xenografts of human tumor cells implanted in immunodeficient mice $[61,63,64]$, as performed according to standard protocols. Depending on compound potency, it may be necessary to consume up to $100 \mathrm{mg}$ of pure compound in the requisite number of mice for this type of testing. It has been our experience that only a small percentage of compounds found to be active in initial in vitro assays have in vivo activity on subsequent biological testing.

We have found the biological testing resources available through the NCI to be highly complementary to our research efforts. For example, the NCI 60-cell line panel provides data on potency and selectivity against various leukemias and solid types of cancer in cell culture $[65,66]$, as well as useful information on mechanism of action through the COMPARE program [e.g., 67]. The RAID ("Rapid Access to Intervention Development") program provides 
resources leading to preclinical development of new anticancer agents [68], and we have accessed this mechanism of support in the past [16].

\section{PROGRAM PROJECT ORGANIZATION}

An organizational scheme of our program project research collaboration is shown in Figure 1. This figure shows the locations of each project and core, and the major technical activities carried out. It is intended that the core components are highly integrated with all three of the main projects, with Projects 1-3 focused on the investigation of tropical plants, aquatic cyanobacteria, and filamentous fungi, respectively. The fungi are provided for this collaboration by Mycosynthetix, Inc. We have made use of the Natural Products Repository of the U.S. National Cancer Institute to obtain taxonomically authenticated extracts from selected geographical regions to help prioritize plant collections and recollections [68]. The technical expertise represented by the senior investigators enables all of the following specific aims to be achieved: collection and taxonomic authentication of organisms; development of intellectual property agreements in order to access organisms; initial solvent extraction of organisms; testing of extracts against a wide panel of cell-based and mechanism-based primary in vitro assays; isolation and structure elucidation of in vitro-active principles of initial leads; dereplication of bioactive extracts and chromatographic fractions for previously known bioactive compounds; testing of promising compounds in tumor growth inhibition assays; application of biostatistics for bioassays; pharmaceutical development of highly promising leads; overall project administration. The senior investigators of the project have face-to-face meetings in different locations three times a year, including an annual meeting in the presence of the program project External Advisory Board, comprised of Drs. John M. Cassady, O. Michael Colvin, Susan B. Horwitz, and G. Robert Pettit. The project receives input from the NCI Program Coordinator (Dr. Yali Fu). We are not aware of any other natural product anticancer drug discovery project that has previously been funded by the U.S. National Cancer Institute through the program project (P01) mechanism.

\section{EXAMPLES OF COMPOUNDS RECENTLY ISOLATED AND EVALUATED}

To exemplify compounds isolated in this collaboration in our ongoing work, compounds from three tropical plant leads that have shown some in vivo activity are briefly reviewed below. In each case, a valid benefits-sharing agreement has been in place prior to plant collection. The examples have been chosen to complement those mentioned in the last review article on this project [16], and much progress has resulted as a result of significant interactions between the various groups in our consortial team. However, at this preliminary stage in our program project, work has not progressed sufficiently for examples of active compounds from cyanobacteria and filamentous fungi to be included herein.

\section{Alvaradoins E-N from Alvaradoa haitensis}

In 1999, four compounds in the "alvaradoin" series, alvaradoins A-D, were isolated and characterized from the aerial parts of Alvaradoa jamaicensis Benth., but these were not investigated for their potential anticancer activity [69]. In work carried out at Research Triangle Institute, bioactivity-directed fractionation of an extract of the leaves of Alvaradoa haitiensis Urb. (Picramniaceae), led to the isolation and structure elucidation of ten new anthracenone $C$-glycosides, alvaradoins E-N, in addition to the known compound, chrysophanol [70]. The plant was collected in the Dominican Republic, and the human oral epidermoid carcinoma (KB) cell line was used to monitor the chromatographic fractions for activity. Of these compounds, the pair of epimers, alvaradoins $\mathrm{E}(10 S)(\mathbf{1}$; Figure 2$)$ and $\mathrm{F}(10 R)(\mathbf{2}$;Figure 2) were most highly cytotoxic (KB; $\mathrm{EC}_{50} 0050 \pm 0.019 \mu \mathrm{M}$ and $0.065 \pm 0.026 \mu \mathrm{M}$, respectively), and approximately ten-fold more potent than any of the remaining alvaradoins isolated from A. haitensis leaves. Alvaradoin E (1), the most potently cytotoxic substance, was further 
evaluated in vivo in the P388 assay at Bristol-Myers Squibb where it showed modest antileukemic activity (125\% T/C) at a dose of $0.2 \mathrm{mg} / \mathrm{kg}$ per intraperitoneal (ip) injection. When compound $\mathbf{2}$ (alvaradoin F) was evaluated in the same model, it showed less activity (115\% T/C) at a maximally tolerated dose of $0.4 \mathrm{mg} / \mathrm{kg}$ per ip injection [70]. Using the in vivo hollow fiber model at the University of Illinois at Chicago, alvaradoin E demonstrated significant growth inhibition at the ip site when tested with $\mathrm{KB}, \mathrm{LNCaP}$, and Col2 cells [71]. When alvarodoin E (1) was evaluated in the P388 model in which both the cancer cells and test compound were administered intravenously, the compound was found to be inactive [70], consistent with the results obtained for this compound in the hollow fiber assay, with the cells implanted subcutaneously [71].

A series of experiments was then conducted at the University of Illinois at Chicago to demonstrate that the cytotoxicity of alvaradoin E (1) was mediated through apoptosis. Treatment of prostate cancer cells ( $\mathrm{LNCaP}$ ) for 24 hours or less at concentrations ranging from $70 \mathrm{nM}$ to $1.12 \mu \mathrm{M}$ caused early signs of apoptosis including chromatin condensation (as judged by DAPI analysis) and mitochondrial membrane depolarization (as shown by $\mathrm{DiOC}_{6}$ uptake). Certain late events in apoptosis were also evaluated in HL-60 human promyelocytic leukemia cells by flow cytometry using an annexin V-FITC assay, which assesses cell viability, as well as the TUNEL assay, to measure DNA cleavage. Within 36 hours of exposure, compound 1 was observed to significantly decrease (8.6-fold) cell viability and to increase (10-fold) DNA cleavage [71].

\section{Aculeatins A and B from Amomum aculeatum}

In 2000 and 2001, Heilmann and Sticher and co-workers at ETH-Zurich reported on several compounds of the 1,7-dioxadispiro[5.1.5.2]pentadecane type from the plant, Amomum aculeatum Roxb. (Zingiberaceae), with cytotoxic, antimicrobial, and antiprotozoal activities, including the parent compounds aculeatins A and B [72,73]. As a result of subsequent enantioselective syntheses by the Marco group, the absolute configurations of these two compounds were established as $\mathbf{3}$ (Figure 2) and $\mathbf{4}$ (Figure 2), respectively [74,75]. Owing to the unusual chemotype exhibited by aculeatins $\mathrm{A}$ and $\mathrm{B}$, we felt it worthwhile to more thoroughly investigate this compound class for potential anticancer activity.

In an initial investigation carried out at The Ohio State University, four new compounds with a C-9 hydroxy group, aculeatols A-D, were isolated from the leaves of A. aculeatum collected in Indonesia, along with aculeatins A (3) and B (4) [76]. Also obtained in this investigation was an acyclic compound, $5 R$-hydroxy-1-(4-hydroxyphenyl)-eicosan-3-one, purified from the rachis of the plant, which is a possible precursor for compounds 3 and 4 [76]. Additional phytochemical work on this same plant led to the isolation of compounds inclusive of aculeatol E (5,Figure 2) and amomol A (6,Figure 2). In the latter compound, the cyclohexane ring is cleaved, and the C-12 stereochemistry was established as $R$ by the Mosher ester method, but the C-2 configuration was unresolved [77]. Since a few hundred milligrams of aculeatin A (3) were purified, several semi-synthetic esters and other derivatives of this compound were generated. However, it was found that aculeatin A was the most potently cytotoxic dioxadispiroketal derivative for a small panel of human cancer cell lines (Lu1, lung; LNCaP, prostate; MCF-7, breast) when compared with the various naturally occurring and semisynthetic analogues obtained [77].

Accordingly, aculeatin A (3) was selected for testing in the in vivo hollow fiber assay at the University of Illinois at Chicago. When evaluated against three cancer cells in hollow fibers (Lu1, LNCaP, and MCF-7), the compound inhibited the growth only of MCF-7 cells by 10 $60 \%$ at the dose range $6.25-50 \mathrm{mg} / \mathrm{kg}$ body weight, when administered at the intraperitoneal site [77]. However, when this compound was tested in two in vivo models at Bristol-Myers Squibb (murine P388 lymphocytic leukemia and human A2780 ovarian carcinoma murine 
xenograft models), it was not deemed to be active [77]. Owing to the activity shown in the hollow fiber assay, it may be worthwhile to conduct a xenograft study on aculeatin A (3) using the MCF-7 cell line. Recently, work by Wong et al. [78] has led to the synthesis of several novel complex polyspirocyclic analogs of aculeatin A with enhanced antimalarial activity compared with the parent compound. While not the primary focus of the work, mammalian cell toxicity was determined using K562 human chronic myelogenous leukemic cells, in order to determine antiprotozoal selectivity [78]. Since some of the compounds synthesized were almost two orders of magnitude more highly cytotoxic than aculetatin A (3), then it would seem logical to screen this compound and its analogs against leukemia targets.

\section{Silvestrol and Episilvestrol from Aglaia foveolata}

Our collaborative group has investigated the fruits and twigs of Aglaia foveolata Pannell (Meliaceae; originally misidentified as Aglaia silvestris), collected in Kalimantan, Indonesia, initially as part of our former NCDDG project [79]. (-)-Silvestrol (7;Figure 2), a rocaglate derivative (flavagline) with an unusual pendant dioxanyl ring at C-6, was isolated from both the fruits and twigs of $A$. foveolata by bioassay-guided fractionation, and its structure and absolute stereochemistry determined by spectroscopic data interpretation and by X-ray crystallography [79]. Rocaglate derivatives from Aglaia species are known to be toxic to insects and cancerous mammalian cells $[80,81]$. These cyclopenta[ $b]$ benzofurans inhibit protein synthesis and induce cell cycle arrest in the G2/M-phase [82-84] and are potent and specific inhibitors of tumor necrosis factor alpha (TNF $\alpha$ ) and phorbol 12-myristate 13-acetate (PMA)induced NF- $\kappa$ B activity in human T cells [85]. Thus, silvestrol (7) was shown to be highly cytotoxic against a panel of human cell lines derived from breast, prostate, and lung cancers. The potency of silvestrol $\left(\mathrm{ED}_{50} 1.2\right.$ to $\left.1.5 \mathrm{nM}\right)$ was similar to those observed for paclitaxel $\left(\mathrm{ED}_{50} 0.7\right.$ to $\left.4.7 \mathrm{nM}\right)$ and camptothecin $\left(\mathrm{ED}_{50}=30 \mathrm{nM}\right)$. (+)-Episilvestrol $(\mathbf{8}$; Figure 2), the C-5 $5^{\prime \prime \prime}$ epimer of silvestrol, was isolated and characterized as a minor component of $A$.

foveoleata twigs, and found to be about three-fold less active as a cytotoxic agent than silvestrol [79]. In turn, silvestrol was over two orders of magnitude more potent as a cytotoxic agent than its analogue, methyl rocaglate (9;Figure 2), isolated in our previous work on Aglaia rubiginosa (Hiern) Pannell [79,86]. Compound 9 differs structurally from silvestrol (7) only by the substitution of the functionalized dioxanyl ring of the latter compound at C-6 with a methoxy group at this same position.

These in vitro studies were followed by analysis of silvestrol (7) in vivo [79]. When silvestrol was tested in the hollow fiber assay at the University of Illinois at Chicago at doses up to 5 $\mathrm{mg} / \mathrm{kg}$, silvestrol inhibited proliferation of all cell lines, particularly the LNCaP human prostate cancer line (up to $83 \%$ inhibition with ip administration), showing no detectable gross toxicity to the mice [79]. Silvestrol was also tested in the P388 murine lymphocytic leukemia model at Bristol-Myers Squibb and found to be active at its maximum tolerated dose of $2.5 \mathrm{mg} / \mathrm{kg}$ when administered as five daily ip injections. A maximum increase in lifespan corresponding to a treatment/control (T/C) ratio of $150 \%$ was achieved. When silvestrol was injected intravenously twice daily for five days in the P388 model, a T/C ratio of $129 \%$ was obtained at a cumulative dose of $2 \mathrm{mg} / \mathrm{kg} /$ day [79].

Two cytotoxic and antineoplastic compounds with the same NMR spectroscopic properties as silvestrol and episilvestrol have been reported in the patent literature from the bark of a Malaysian plant, Aglaia leptantha Miq., with one of the compounds found to inhibit the growth of PC3 human prostate cancer cells in a xenograft study [87]. However, the inventors did not assign the full stereochemistry to either of these compounds. Very recently, (-)-silvestrol has been totally synthesized by the Porco and Rizzacasa groups [88,89]. In follow-up phytochemical work conducted recently at the The Ohio State University, silvestrol (7) was found to occur in the leaves of A. foveolata collected in Indonesia, so that this plant part could 
be used as a renewable resource for the production of silvestrol, in the event this compound continues to show promise [90].

At the University of Illinois at Chicago, studies have been conducted to elucidate the cellular mechanism of action of silvestrol (7) in LNCaP cells. It was revealed by microarray analysis of the molecular signature induced in cultured LNCaP cells by silvestrol that 20 apoptosis and cell cycle related genes were significantly altered [91]. Up-regulated genes included p21 (a potent cyclin-dependent kinase inhibitor that is governed by p53), and p300 (a transcription factor co-regulator). Compound 7 was found to down-regulate p53 at the RNA and protein level within 15 minutes of exposure, and, within 6 hours of silvestrol exposure, no p53 could be detected by immunoblot. Also observed was down-regulation of MDM2, the E3 ligase specific for $\mathrm{p} 53$, which was not prevented by lactacystin, suggesting that silvestrol-induced degradation of $\mathrm{p} 53$ is not mediated by the proteasome. Cell cycle analysis by flow cytometry demonstrated that silvestrol induces a block in the cycle at the $\mathrm{G}_{2} / \mathrm{M}$ checkpoint [91].

Moreover, cell-cycle arrest induced by silvestrol (7) led to cell death by apoptosis [92]. A follow-up investigation at the University of Illinois at Chicago on the mechanism of apoptosis induction in $\mathrm{LNCaP}$ cells revealed that silvestrol disrupted the mitochondrial trans-membrane potential and caused cytochrome $\mathrm{c}$ release into the cytoplasm. Compound $\mathbf{7}$ produced an increase of Bcl-xl phosphorylation and increased Bak expression. Caspases-2, -9 and -10 were demonstrated to be involved in silvestrol-mediated apoptosis, while caspases-3 and -7 were not. Experiments using various cell-permeable inhibitors showed that only the general caspase inhibitor Boc-D-Fmk inhibited the formation of apoptotic bodies completely. This suggests that silvestrol induces the apoptosome/mitochondrial pathway to stimulate apoptosis in treated LNCaP cells [92].

Pelletier and colleagues have shown recently that silvestrol (7) can inhibit translation in eukaryotic cells and enhance the sensitivity of lymphoma cells to doxorubicin [93]. The eukaryotic translation initiation factor (eIF) $4 \mathrm{~F}$ is a complex that stimulates ribosome recruitment to mRNA. Silvestrol targets eIF4A to prevent its association with eIF4FE and eIF4FG, thus preventing the formation of the eIF4F complex and subsequent translation. These findings suggest a novel mechanism for the antitumor activity of silvestrol [93].

Recent studies by Grever and Lucas at The Ohio State University Medical Center, outside the scope of our current program project, have suggested that the cytotoxicity of silvestrol (7) is selective for B cells relative to T cells [94,95]. In their work, silvestrol was found initially to be selectively cytotoxic for chronic lymphocytic leukemia (CLL) cells relative to normal peripheral blood monocyte cells, with its cell killing independent of two key resistance factors, p53 and Bcl-2 [94]. The B-cell-specific activity was observed both ex vivo and in vivo using the Tcl-1 transgenic murine model of CLL. Silvestrol significantly decreased leukemic B cells in vivo, without detectable effects on $\mathrm{T}$ cell count. Silvestrol caused a rapid proteasome independent reduction in Mcl-1 protein, which is a member of the Bcl-2 family of proteins associated with the outer mitochondrial membrane [95]. In October, 2007, the Drug Development Group of the U.S. National Cancer Institute selected silvestrol for preclinical evaluation at the IIA level (including additional sourcing of the plant of origin and preliminary formulation, pharmacokinetics, and toxicology), potentially leading to clinical development.

\section{Acknowledgments}

The authors of this chapter wish to acknowledge financial support through grants U19-CA52956 and P01-CA125066 from the National Cancer Institute, National Institutes of Health, Bethesda, Maryland. We are grateful to our taxonomic collaborators in several countries for their kind cooperation with plant collections. We wish to thank many present and former faculty and staff colleagues, postdoctoral associates, and graduate students who have participated in this collaborative project, and whose names are included in the bibliography below. 


\section{References}

1. American Cancer Society. Cancer Facts and Figures 2008. Atlanta: American Cancer Society; 2008.

2. Stewart, B.; Kleihues, P., editors. World Cancer Report (World Health Organization, International Agency for Cancer Research). IARC Press; Lyon: 2003.

3. Parkin DM. Lancet Oncol 2001;2:533-543. [PubMed: 11905707]

4. Chabner, BA.; Amrein, PC.; Druker, B.; Michaelson, MD.; Mitsiades, CS.; Gross, PE.; Ryan, DP.; Ramachandra, S.; Richardson, PG.; Supko, JG.; Wilson, WH. Goodman \& Gilman's The Pharmacological Basis of Therapeutics. Vol. 11. Brunton, LL.; Laso, JS.; Parker, KL., editors. McGraw-Hill; New York: 2005. p. 1315-1403.

5. DeVita, VT.; Hellman, S.; Rosenberg, SA., editors. Cancer: Principles and Practice of Oncology. Vol. 8. Lippincott-Williams \& Wilkins; Philadelphia: 2008.

6. Workman P. Curr Cancer Drug Targets 2001;1:33-47. [PubMed: 12188890]

7. Cragg, GM.; Kingston, DGI.; Newman, DJ. Anticancer Agents from Natural Products. CRC Press; Boca Raton, FL: 2005.

8. Butler MS. Nat Prod Rep 2005;22:162-195. [PubMed: 15806196]

9. Newman DJ, Cragg GM. J Nat Prod 2007;70:461-477. [PubMed: 17309302]

10. Butler MS. Nat Prod Rep 2008;25:475-516. [PubMed: 18497896]

11. Henkel T, Brunne RM, Miiller H, Reichel F. Angew Chem Int Ed 1999;38:643-647.

12. Feher M, Schmidt JM. J Chem Inf Comp Sci 2003;43:218-227.

13. Ortholand JY, Ganesan A. Curr Opin Chem Biol 2004;8:271-280. [PubMed: 15183325]

14. Kingston DGI, Newman DJ. Curr Opin Drug Disc Devel 2002;5:304-316.

15. Kinghorn AD, Farnsworth NR, Soejarto DD, Cordell GA, Pezzuto JM, Udeani GO, Wani MC, Wall ME, Navarro HA, Kramer RA, Menendez AT, Fairchild CR, Lane KE, Vyas DM, Lam KS, Shu YZ. Pure Appl Chem 1999;71:1611-1618.

16. Kinghorn AD, Farnsworth NR, Soejarto DD, Cordell GA, Swanson SM, Pezzuto JM, Wani MC, Wall ME, Oberlies NC, Kroll DJ, Kramer RA, Rose WC, Vite GD, Fairchild CR, Peterson RW, Wild R. Pharm Biol 2003;41(Suppl):53-64.

17. Cragg GM, Newman DJ. J Nat Prod 2004;67:232-244. [PubMed: 14987065]

18. Gerwick, W.; Tan, LT.; Sitachitta, N. The Alkaloids. Cordell, GA., editor. Vol. 57. Academic Press; San Diego: 2001. p. 75-184.

19. Clardy J, Walsh C. Nature 2004;432:829-837. [PubMed: 15602548]

20. Singh S, Kato BN, Banerjee UC. Crit Rev Biotechnol 2005;25:73-95. [PubMed: 16294828]

21. Sielaff H, Christiansen G, Schwecke T. IDrugs 2006;9:119-127. [PubMed: 16523402]

22. Welker M, von Dohren H. FEMS Microbiol Rev 2006;30:530-563. [PubMed: 16774586]

23. Rohr J. ACS Chem Biol 2006;1:747-750. [PubMed: 17240971]

24. Harigan, G.; Luesch, H.; Moore, RE.; Paul, VJ. Special Publication No. 257 (Biodiversity). Royal Society of Chemistry; London: 2000. p. 126-139.

25. Patterson GML, Baldwin CL, Bolis CM, Caplan FR, Karuso H, Larsen LK, Levine IA, Moore RE, Nelson CS, Tschappat KD, Furusawa E, Furusawa S, Norton TR, Raybourne RB. J Phycol 1991;27:530-536.

26. Sulkowska-Ziaja K, Muszynska B, Konska G. Acta Pol Pharm 2005;62:153-160. [PubMed: 16161358]

27. Satiat-Jeunemaitre B, Hawes C. Cell Biol Int 1993;17:183-193.

28. Udagawa T, Yuan J, Panigrahy D, Chang YJ, Shah J, D’Amato RJ. J Pharmacol Exp Ther 2000;294:421-427. [PubMed: 10900214]

29. Lee HJ, Lee JH, Hwang BY, Kim HS, Lee JJ. Arch Pharm Res 2001;24:397-401. [PubMed: 11693538]

30. Keiner MJ, McMorris TC, Rojas RK, Estes LA, Suthipinijtham P. Inv New Drugs 2008;26:407-415.

31. McCloud TG, Klueh PA, Pearl KC, Carter LK, Mushik GM, Poole KK. Nat Prod Lett 1996;9:8795.

Pure Appl Chem. Author manuscript; available in PMC 2010 January 1. 
32. Turbyville TJ, Wijeratne EMK, Whitesell L, Gunatilaka AAL. Mol Cancer Ther 2005;4:1569-1576. [PubMed: 16227407]

33. Ui M, Okada T, Hazeki K, Hazeki O. Trends Biochem Sci 1995;20:303-307. [PubMed: 7667888]

34. Kusaka M, Sudo K, Matsutani E, Kozai Y, Marui S, Fujita T, Ingber D, Folkman J. Br J Cancer 1994;69:212-216. [PubMed: 8297716]

35. Satchi-Fainaro R, Puder M, Davies JW, Tran HT, Sampson DA, Greene AK, Corfas G, Folkman J. Nature Med 2004;10:255-261. [PubMed: 14981512]

36. Burslem DFRP, Garwood NC, Thomas SC. Science 2001;291:606-607. [PubMed: 11158665]

37. Myers N, Mittermeier RA, Da Fonseca GAB, Kent J. Nature (London) 2000;403:853-858. [PubMed: 10706275]

38. Pitman NCA, Jorgensen PM. Science 2002;298:989. [PubMed: 12411696]

39. Mendelsohn R, Balick MJ. Econ Bot 1995;49:223-228.

40. Artuso, A. Economic and Policy Aspects of Discovery, Development, and Marketing. Pharmaceutical Products Press; New York: 1997. Drugs of Natural Origin.

41. Balunas MJ, Jones WP, Chin YW, Mi Q, Farnsworth NR, Soejarto DD, Cordell GA, Swanson SM, Pezzuto JM, Chai HB, Kinghorn AD. Chem Biodivers 2006;3:897-914. [PubMed: 17193321]

42. Wall ME, Wani MC, Brown DM, Fullas F, Oswald JB, Josephson FF, Thornton NM, Pezzuto JM, Beecher CWW, Farnsworth NR, Cordell GA, Kinghorn AD. Phytomedicine 1996;3:281-286.

43. Jones, WP.; Chai, H-B.; Mi, Q.; Farnsworth, NR.; Swanson, SM.; Cordell, GA.; Kinghorn, AD. 44th Annual Meeting of the American Society of Pharmacognosy; July 12-16; Chapel Hill, NC: University of North Carolina; 2003. Abstract P-231

44. Kautz RA, Goetzinger W, Karger BL. J Comb Chem 2005;7:14-20. [PubMed: 15638474]

45. Hawkesworth DL. Mycol Res 1991;95:641-655.

46. Seo EK, Kim NC, Mi Q, Chai H, Wall ME, Wani MC, Navarro HA, Burgess JP, Graham JG, Cabieses F, Tan GT, Farnsworth NR, Pezzuto JM, Kinghorn AD. J Nat Prod 2001;64:1483-1485. [PubMed: 11720542]

47. Alali FQ, Tawaha K, El-Elimat T, Qasaymeh R, Li C, Burgess J, Nakanishi Y, Kroll DJ, Wani MC, Oberlies NH. Nat Prod Res, Part A: Struct Synth 2006;20:558-566.

48. Thanos D, Maniatis T. Cell 1995;80:529-532. [PubMed: 7867060]

49. Masuda ES, Imamura R, Amasaki Y, Arai K, Arai N. Cell Signalling 1998;10:599-611. [PubMed: 9794241]

50. Ding GJF, Fischer PA, Boltz RC, Schmidt JA, Colaianne JJ, Gough A, Rubin RA, Miller DK. J Biol Chem 1998;273:28897-28905. [PubMed: 9786892]

51. Nowak G. J Biol Chem 2002;277:43377-43388. [PubMed: 12218054]

52. Varambally S, Dhanasekaran SM, Zhou M, Barrette TR, Kumar-Sinha C, Sanda MG, Ghosh D, Pienta KJ, Sewalt RG, Otte AP, Rubin MA, Chinnaiyan AM. Nature 2002;419:624-629. [PubMed: 12374981]

53. Kleer CG, Cao Q, Varambally S, Shen R, Ota I, Tomlins SA, Ghosh D, Sewalt RG, Otte AP, Hayes DF, Sabel MS, Livant D, Weiss SJ, Rubin MA, Chinnaiyan AM. Proc Natl Acad Sci USA 2003;100:11606-11611. [PubMed: 14500907]

54. Dokmanovic M, Marks PA. J Cell Biochem 2005;96:293-304. [PubMed: 16088937]

55. Moradei O, Maroun CR, Paquin I, Vaisburg A. Curr Med Chem Anticancer Agents 2005;5:529-560. [PubMed: 16178777]

56. Adams J. Trends Mol Med 2002;8(Suppl):S49-S54. [PubMed: 11927288]

57. Su BN, Hwang BY, Chai H, Carcache-Blanco EJ, Kardono LBS, Afriastini JJ, Riswan S, Wild R, Laing N, Farnsworth NR, Cordell GA, Swanson SM, Kinghorn AD. J Nat Prod 2004;67:1911-1914. [PubMed: 15568789]

58. Casciari JJ, Hollingshead MG, Alley MC, Mayo JG, Malspeis L, Miyauchi S, Grever MR, Weinstein JN. J Natl Cancer Inst 1994;86:1846-1852. [PubMed: 7990159]

59. Hollingshead MG, Alley MC, Camalier RF, Abbott BJ, Mayo JG, Malspeis L, Grever MR. Life Sci 1995;57:131-141. [PubMed: 7603295] 
60. Hall LA, Krauthauser CM, Wexler RS, Hollingshead MG, Slee AM, Kerr JS. Anticancer Res 2000;20:903-911. [PubMed: 10810375]

61. Mi Q, Lantvit D, Reyes-Lim E, Chai H, Zhao W, Lee IS, Peraza-Sanchez S, Ngassapa O, Kardono LBS, Riswan S, Hollingshead MG, Mayo JG, Farnsworth NR, Cordell GA, Kinghorn AD, Pezzuto JM. J Nat Prod 2002;65:842-850. [PubMed: 12088425]

62. Rose WC, Schurig JE, Meeker JB. Anticancer Res 1988;8:355-358. [PubMed: 3389740]

63. Rose WC, Basler GA. In Vivo 1991;4:391-396. [PubMed: 2103379]

64. Rose WC, Crosswell AR, Schurig JE, Casazza AM. Cancer Chemother Pharmacol 1993;32:197-203. [PubMed: 8500224]

65. Boyd MR, Paull KD. Drug Devel Res 1995;34:91-109.

66. Shoemaker RH. Nature Rev Cancer 2006;6:813-823. [PubMed: 16990858]

67. Zhou BN, Hoch JM, Johnson RK, Mattern MR, Eng WK, Ma J, Hecht SM, Newman DJ, Kingston DGI. J Nat Prod 2000;63:1273-1276. [PubMed: 11000035]

68. Hallock YF, Cragg GM. Pharm Biol 2003;41(Suppl):78-91.

69. Harding WW, Henry CE, Lewis PA, Jacobs H, McLean S, Reynolds WF. J Nat Prod 1999;62:98101. [PubMed: 9917291]

70. Phifer SS, Lee D, Seo EK, Kim NC, Graf TN, Kroll DJ, Navarro HA, Izydore RA, Jimenez F, Garcia R, Rose WC, Fairchild CR, Wild R, Soejarto DD, Farnsworth NR, Kinghorn AD, Oberlies NH, Wall ME, Wani MC. J Nat Prod 2007;70:954-961. [PubMed: 17552563]

71. Mi Q, Lantvit D, Reyes-Lim E, Chai H, Phifer SS, Wani MC, Wall ME, Tan GT, Cordell GA, Farnsworth NR, Kinghorn AD, Pezzuto JM. Anticancer Res 2005;25:779-787. [PubMed: 15868909]

72. Heilmann J, Mayr S, Brun R, Rali T, Sticher O. Helv Chim Acta 2000;83:1281-1285.

73. Heilmann J, Brun R, Mayr S, Rali T, Sticher O. Phytochemistry 2001;57:1281-1285. [PubMed: 11454360]

74. Falomir E, Alvarez-Bercedo P, Carda M, Marco JA. Tetrahedron Lett 2005;46:8407-8410.

75. Alvarez-Bercedo P, Falomir E, Carda M, Marco JA. Tetrahedron 2006;62:9641-9649.

76. Salim AA, Su BN, Chai HB, Riswan S, Kardono LBS, Ruskandi A, Farnsworth NR, Swanson SM, Kinghorn AD. Tetrahedron Lett 2007;48:1849-1853. [PubMed: 18320008]

77. Chin YW, Salim AA, Su BN, Mi Q, Chai HB, Riswan S, Kardono LBS, Ruskandi A, Farnsworth NR, Swanson SM, Kinghorn AD. J Nat Prod 2008;71:390-395. [PubMed: 18260638]

78. Peuchmaur M, Saidani N, Botte C, Marechal E, Vial H, Wong YS. J Med Chem 2008;51:4870-4873. [PubMed: 18680278]

79. Hwang BY, Su BN, Chai H, Mi Q, Kardono LBS, Afriastini JJ, Riswan S, Santarsiero BD, Mesecar AD, Fairchild CR, Wild R, Vite GR, Rose WC, Farnsworth NR, Cordell GA, Pezzuto JM, Swanson SM, Kinghorn AD. J Org Chem 2004;69:3350-3358. erratum ibid.69, 6156 (2004). [PubMed: 15132542]

80. Proksch P, Edrada RA, Ebel R, Bohnenstengel FI, Nugroho BW. Curr Org Chem 2001;5:923-938.

81. Kim S, Salim AA, Swanson SM, Kinghorn AD. Anticancer Agents Med Chem 2006;6:319-345. [PubMed: 16842234]

82. Ohse T, Ohba S, Yamamoto T, Koyano T, Umezawa K. J Nat Prod 1996;59:650-652. [PubMed: 8759160]

83. Bohnenstengel FI, Steube KG, Meyer C, Quentmeier H, Nugroho BW, Proksch P. Z Naturforsch [C] 1999;54:1075-1083.

84. Lee SK, Cui B, Mehta RR, Kinghorn AD, Pezzuto JM. Chem-Biol Interact 1998;115:215-228. [PubMed: 9851291]

85. Baumann B, Bohnenstengel F, Siegmund D, Wajant H, Weber C, Herr I, Debatin KM, Proksch P, Wirth T. J Biol Chem 2002;277:44791-44800. [PubMed: 12237314]

86. Rivero-Cruz JF, Chai HB, Kardono LBS, Setyowati FM, Afriastini JJ, Riswan S, Farnsworth NR, Cordell GA, Pezzuto JM, Swanson SM, Kinghorn AD. J Nat Prod 2004;67:343-347. [PubMed: 15043407]

87. Meurer-Grimes, BM.; Yu, J.; Vairo, GL. US Patent. 6710075 B2. 2004.

88. Gerard B, Cencic R, Pelletier J, Porco JA. Angew Chem Int Edit 2007;46:7831-7834. 
89. El Sous M, Khoo ML, Holloway G, Owen D, Scammells PJ, Rizzacasa MW. Angew Chem Int Edit 2007;46:7835-7838.

90. Salim AA, Chai HB, Rachman I, Riswan S, Kardono LBS, Farnsworth NR, Carcache-Blanco EJ, Kinghorn AD. Tetrahedron 2007;63:7926-7934. [PubMed: 18698338]

91. Mi Q, Kim S, Hwang BY, Su BN, Chai H, Arbieva ZH, Kinghorn AD, Swanson SM. Anticancer Res 2006;26:3349-3356. [PubMed: 17094452]

92. Kim S, Hwang BY, Su BN, Chai H, Mi Q, Kinghorn AD, Swanson SM. Anticancer Res 2007;27:2175-2184. [PubMed: 17695501]

93. Bordeleau ME, Robert F, Gerard B, Lindqvist L, Chen SM, Wendel HG, Brem B, Greger H, Low SW, Porco JA, Pelletier J. J Clin Invest 2008;118:2651-2660. [PubMed: 18551192]

94. Edwards, RB.; Lucas, DM.; Lozanski, G.; Johnson, AJ.; Su, B-N.; Lin, TS.; Byrd, JC.; Kinghorn, AD.; Grever, MR. Abstract presented at the 48th Annual Meeting of the American Society of Hematology; Orlando, FL. December 9-12; 2006.

95. Edwards, RB.; Lucas, DM.; West, DA.; De Lay, MD.; Lozanski, G.; Johnson, AJ.; Salim, AA.; Lin, TS.; Byrd, JC.; Kinghorn, AD.; Grever, MR. Abstract presented at the 49th Annual Meeting of the American Society of Hematology; Atlanta, GA. December 8-11; 2007. 


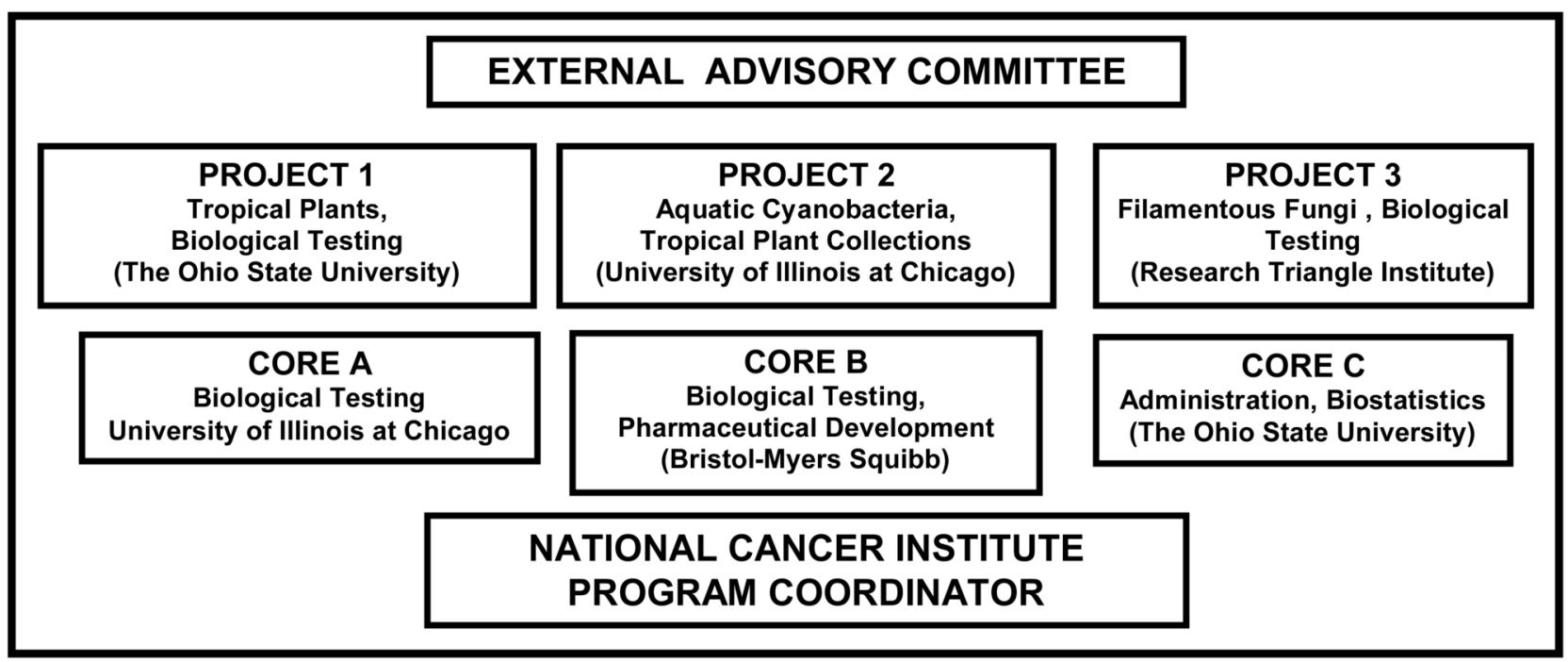

Figure 1.

Organizational Scheme of Program Project 
<smiles>Cc1cc(O)c2c(c1)[C@H]1C(O)C(O)c3c(O)cc(C)cc3[C@]1(C)c1cccc(O)c1C2=O</smiles>

Alvaradoin E (1)

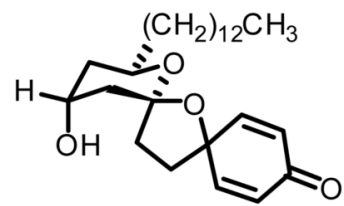

Aculeatin B (4)

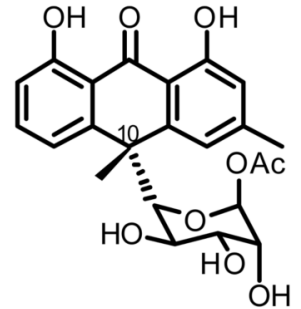

Alvaradoin F (2)

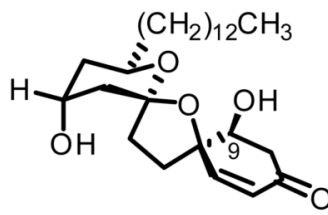

Aculeatol E (5)

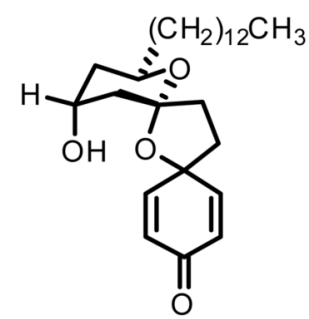

Aculeatin A (3)<smiles>CCCCCCCC(O)[C@H](O)C1(OC)CCC2(C=CC(=O)C=C2)O1</smiles>

Amomol A (6)<smiles>COC(=O)[C@H]1C[C@]2(O)c3c(OC)cc(O[C@@H]4O[C@H]([C@@H](O)CO)CO[C@H]4OC)cc3O[C@]2(c2ccc(OC)cc2)[C@@H]1c1ccccc1</smiles>

Silvestrol $\quad\left(5^{\prime \prime \prime} R\right) \quad(7)$ Episilvestrol (5'" S) (8)

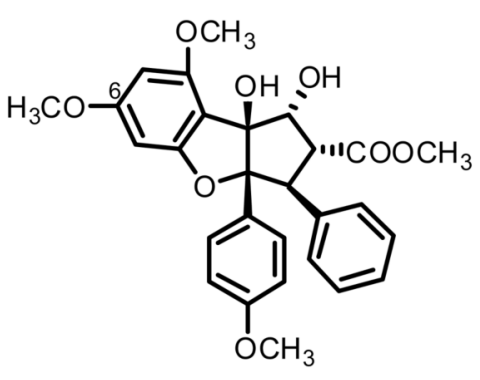

Methyl rocaglate (9)

Figure 2.

Structures of Compounds Isolated During Collaborative Work 